«Системні технологіï» 1 (126) 2020 «System technologies»

DOI 10.34185/1562-9945-1-126-2020-13

UDK $621.373-187.4$

M. Tverdostup

\title{
ABOUT SYNTHESIS OF INDUCTIVITY MULTIPLIERS BASED ON GENERALIZED MODEL OF IMPEDANCE CONVERTERS
}

Abstract. Using a generalized model of impedance converters converters of grounded and weighted inductances into a grounded inductance, in which separate control of the values of the components of the synthesized inductive impedance is implemented.

Keywords: synthesis, inductance, impedance, converter, operational amplifier, feedback, multiplier.

Introduction. The creation of functional devices for receiving and primary processing of information from passive measuring sensors is an urgent task. In some cases, to solve this problem, it is advisable to use impedance converters [1]. The development of impedance converters can be greatly simplified by having their basic model. In [2], a generalized model of impedance transducers is presented, which is promising for use as a base when creating the corresponding transducers for passive measuring transducer parameters.

Formulation of the problem. The aim of the work is to determine the possibilities of using a generalized model of impedance converters for the synthesis of multipliers of grounded and weighted (non-grounded) inductance.

Main part. Generalized model of impedance converters. In [2], it was shown that an operational amplifier with combined feedback (Fig. 1) has a functionally complete set of input impedances in the form

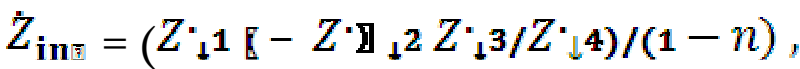

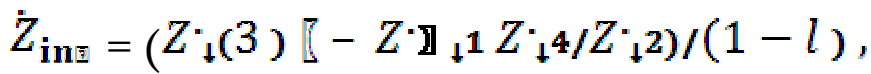

$$
\begin{aligned}
& \dot{Z}_{\text {inฐ }}=\left(\dot{Z}_{2 \llbracket}-Z \cdot \rrbracket_{\downarrow} 1 Z_{\downarrow}{ }_{\downarrow} 4 / Z_{\downarrow}{ }^{*} 3\right) /(1-k) \text { ， }
\end{aligned}
$$

(C) Tverdostup M., 2020 
«Системні технологіï» 1 (126) 2020 «System technologies»

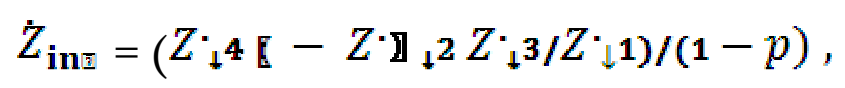

where $\dot{Z}_{1}, \dot{Z}_{2}, \dot{Z}_{3}, \dot{Z}_{4}$ - are linear impedances of an arbitrary nature; $U_{1}, U_{2}$, $U_{3}, U_{4}$ - voltage of the excitation sources; $n=U_{2} / U_{1}, l=U_{1} / U_{2}, k=U_{4} / U_{3}$,

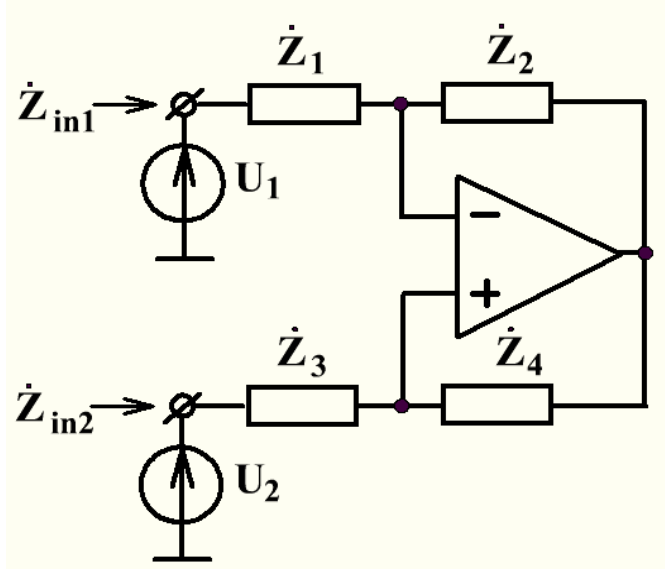

a)

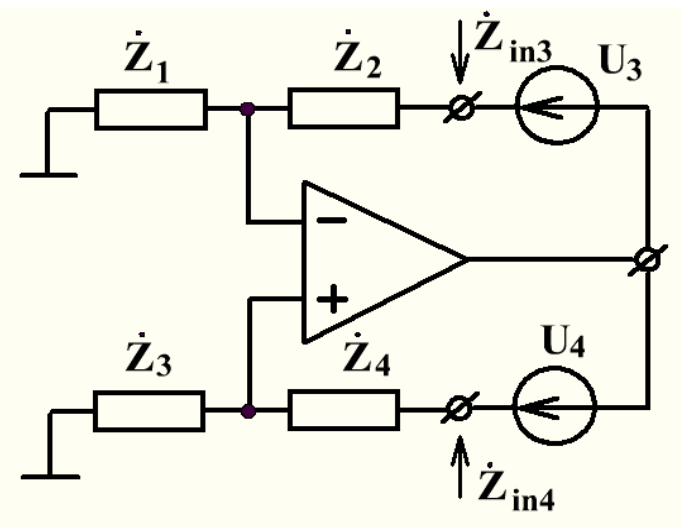

b)

Figure 1 - Generalized model of impedance converters with grounded (a) and weighted (b) excitation sources

$p=U 3 / U 4$. The values and signs of the components of the four possible input impedances $\dot{Z}_{\text {in1 }}-Z_{\text {iI4 }}$ are determined by the amplitude and phase relationships between the voltages of the excitation sources.

Synthesis of a grounded inductive impedance multiplier. We transform the grounded inductive impedance based on a generalized model with grounded excitation voltage sources (Fig. 1a) by choosing $\dot{Z}_{1}=0$ and U2 $=0$. Then it follows from (1) that $\mathrm{n}=0$, and the input impedance $\dot{Z}_{\text {ins }}$ has the form:

$$
\dot{Z}_{\text {inฐ }}=\frac{-\dot{Z}_{2} \dot{Z}_{3}}{\dot{Z}_{4}} .
$$

In this case, with respect to $\dot{Z}_{2}$ and $\dot{Z}_{3}$, the generalized model is a negative impedance converter, on the basis of which it is possible to multiply the inductive impedance by double converting it.

To implement double conversion, we select (Fig. 2) two seriesconnected negative impedance converters on DA1 and DA2, for which $R_{2}, R_{3}, R_{4}, R_{2}, R_{4}$ are used as linear impedances. The grounded inductance $L_{0}$ 
«Системні технології» 1 (126) 2020 «System technologies»

to be multiplied with the active resistance $r_{0}$ is included in the place of the grounded impedance $\dot{Z}_{\mathbf{3}}$.

Under these conditions, the input impedance converter on DA2 according to (5) is equal to

$$
\dot{Z}_{\text {in }}=-\frac{R_{2}\left(r_{0}+\mathbf{j} \omega L_{0}\right)}{R_{4}^{\frac{\pi}{\pi}}},
$$

it is converted with a change of sign by the DA1 converter to

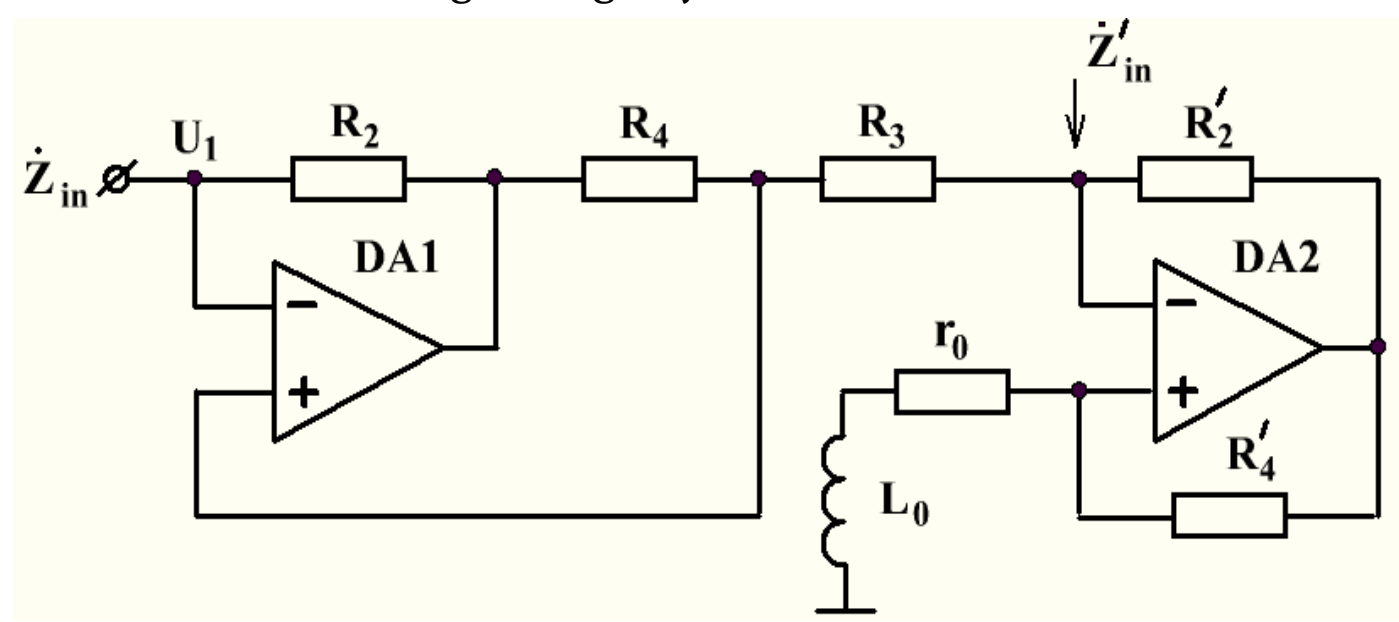

Figure 2 - The multiplier of the grounded inductance $L_{0}$ on two negative impedance converters

$$
\dot{Z}_{\text {i }}=-\frac{R_{2}\left(R_{3}+\dot{Z}_{\mathrm{in}}\right)}{R_{\boxplus}} .
$$

Then, taking into account (6), the input impedance of the DA1 converter becomes equal

$$
\dot{Z}_{\text {i }}=-\frac{R_{2} R_{3}}{R_{4}}+\frac{R_{2} R_{2} r_{0}}{R_{4} R_{4}}+\frac{\mathrm{j} \omega L_{0} R_{2} R_{2}}{R_{4} R_{4}} .
$$

The resulting input impedance $\dot{Z}_{\text {in }}=r_{\text {in }}$ is inductive, represents a grounded inductance $L_{\mathbf{i n}_{\mathbf{n}}}$ with a series-connected active resistance $r_{\mathbf{i}_{\mathbf{n}}}$, the values of which are equal to (7)

$$
\begin{aligned}
& r_{\text {in }}=\frac{R_{2}\left(\frac{R_{2} r_{0}}{R_{4}}-R_{3}\right)}{R_{4}}, \\
& L_{\text {in }}=\frac{L_{0} R_{2} R_{2}}{R_{4} R_{4}} .
\end{aligned}
$$


«Системні технологіï» 1 (126) 2020 «System technologies»

From the last expressions it follows that in this circuit, a grounded controlled inductance $L_{\mathbf{i n}_{\mathbf{n}}}$ is synthesized, the value of which is determined as the result of multiplying the inductance $L_{0}$ by the conversion coefficient equal to $\frac{R_{2} R_{2}}{R_{4} R_{4}}$.

The synthesized active resistance $r_{\mathbf{i n}}$ can take both positive and negative values depending on the resistance value $R_{3}$ in comparison with $\frac{R_{2} r_{0}}{R_{4}}$. When the equality $R_{3}=\frac{R_{2} r_{0}}{R_{4}}$ is fulfilled, the input resistance, which minimizes the active losses of the synthesized inductance and significantly increases its quality factor.

Synthesis of a weighted inductive impedance multiplier. To build a non-grounded impedance multiplier, we select equation (1) for in-phase excitation voltages and $\mathrm{U} 2<\mathrm{U} 1$. Then, from the generalized model (Fig. 1a), the variant of the multiplier in Fig. 3, wherein $\dot{Z}_{1}=r_{0}+\mathbf{j} \omega L_{\Xi}$ - complex impedance of multiplied inductance $L_{0}$ with active resistance $r_{0} ; R_{2}, R_{3}, R_{4}$ - active resistances of the combined feedback circuit of the amplifier DA2.

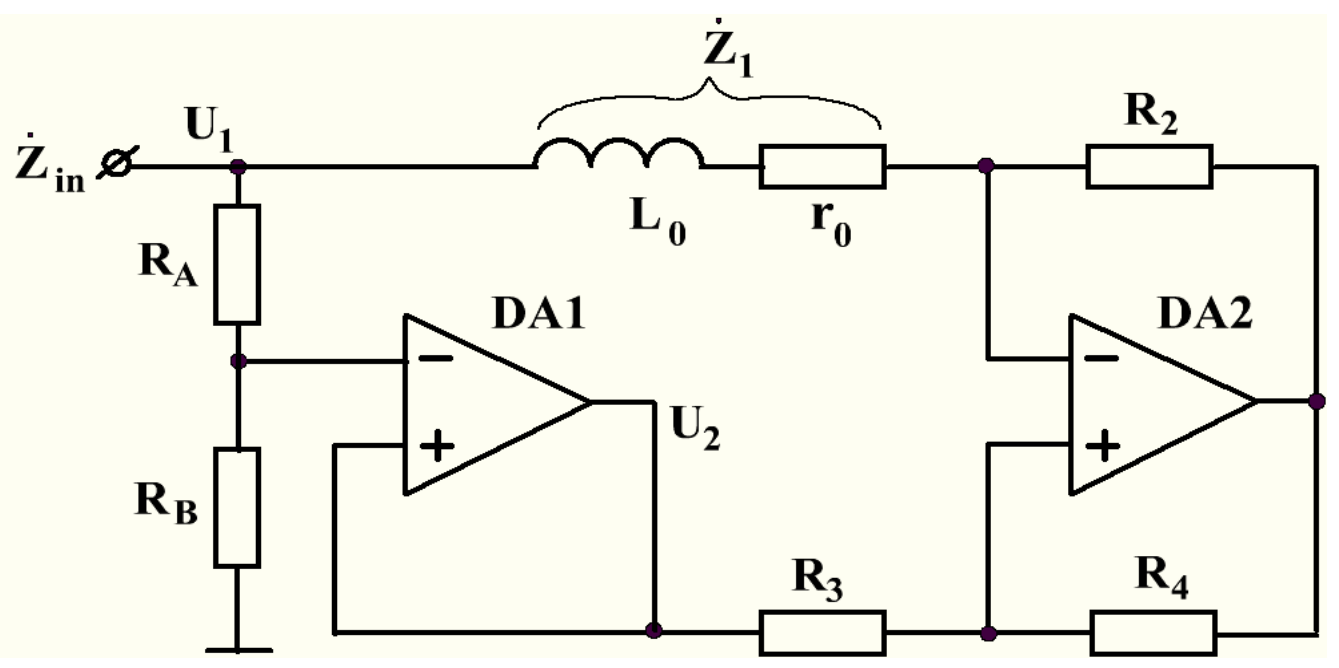

Figure 3 - Weighted inductance multiplier $L_{\mathbf{0}} \mathrm{S}$ active resistance $r_{\mathbf{0}}$

The repeater on the amplifier DA1 with the divider RA, RB is an auxiliary device for the implementation of the excitation voltage source $\mathrm{U} 2$, in phase voltage $\mathrm{U} 1$. The ratio of the voltage of the excitation sources, in this case, has the form 


\section{«Системні технології» 1 (126) 2020 «System technologies»}

$n=R_{\mathbf{B}} /\left(R_{\mathbf{A}}+R_{\mathbf{B}}\right)$. Under such conditions, it follows from (1) that the input impedance of the circuit in Fig. 3 is equal

$$
\dot{Z}_{\mathrm{in}}=\left(1+R_{\mathrm{B}} /\left(R_{\mathrm{A}}\right)\left(r_{1}+\mathbf{j} \mathbf{\omega} L_{\mathbf{1}}-\frac{R_{2} R_{3}}{R_{4}}\right)\right) .
$$

In (10), we select the real and imaginary parts and obtain, respectively, the expressions for the input active resistance rin and input inductance Lin as components of the synthesized input impedance $\dot{Z}_{\text {iฐ }}$

$$
\begin{aligned}
r_{\text {in }} & =\left(1+\frac{R_{\mathrm{B}}}{R_{\mathrm{A}}}\right)\left(r_{0}-\frac{R_{2} R_{3}}{R_{4}}\right), \\
L_{\text {in }} & =\left(1+\frac{R_{\mathrm{B}}}{R_{\mathrm{A}}}\right) L_{0} .
\end{aligned}
$$

It follows from (11) and (12) that the inductance LO and active resistance $\mathrm{r} 0$ are converted into the input inductance $L_{\mathbf{i n}}$ and resistance $r_{\mathrm{in}}$ with a conversion coefficient $\left(1+\frac{R_{\mathrm{B}}}{R_{\mathrm{A}}}\right)$, the value of which can be controlled over a wide range of resistances RA, RB of the divider. It also follows from (11) that the multiplication of the resistance $\mathrm{r} 0$ is accompanied by its compensation of the negative active component of the input impedance $R_{(-)}=-\frac{R_{2} R_{3}}{R_{4}}$, and if $R_{\mathrm{f}-\mathrm{S}} \rightarrow \mathrm{r} 0$, then the input resistance $r_{\mathrm{in}} \rightarrow 0$. This indicates a significant increase in the quality factor of the synthesized inductance.

Conclusions. As a result of the analysis established:

- synthesized multipliers of grounded and weighted inductive impedances are converters only to grounded impedance;

- the developed impedance multipliers allow separate control of the values of the synthesized inductance and its active resistance, which can take positive and negative values of a given value;

- a generalized model of impedance converters can be used as a basic circuit for constructing inductance multipliers. 
«Системні технології» 1 (126) 2020 «System technologies»

\section{ЛИТЕРАТУРА / ЛІТЕРАТУРА}

1. Филановский И.М., Персианов А. Ю., Рыбин В.К. Схемы с преобразователями сопротивления. Л.: Энергия, 1973. 192 с.

2. Твердоступ Н.И. Обобщенная модель преобразователей импеданса. Biсник Дніпропетр. ун-ту. Фізика. Радіоелектроніка. 2010. Вип. 17, №2. С. $103-108$.

\section{REFERENCES}

1. Fylanovskyi I.M., Persyanov A. Yu., Rybin V.K. Skhemy s preobrazovateliamy soprotivlenia. L.: Energia, 1973. $192 \mathrm{s.}$

2. Tverdostup N.I. Obobshchyonnaia model preobrazovatelej impedansa. Visnyk Dnipropetr. un-tu. Fizyka. Radioelektronika. 2010. Vyp. 17, №2. S. 103 108.

Received 23.01.2020. Accepted 28.01.2020.

О синтезе умножителей индуктивности на основе обобщенной модели преобразователей импеданса

На основе обобщенной модели преобразователей импеданса разработаны преобразователи заземленной и взвешенной індуктивностей в заземленную индуктивность, в которых реализовано раздельное управление величинами составляющих синтезированного импеданса.

Про синтез помножувачів індуктивності на основі узагальненої моделі перетворювачів імпедансу

На основі узагальненої моделі перетворювачів імпедансу розроблені перетворювачі заземленої і зваженої індуктивностей в заземлену індуктивність, в якій реалізоване роздільне управління величинами складових синтезованого імпедансу.

Твердоступ Николай Иванович - доцент, к.т.н., доцент кафедры электронных вычислительных машин Днепровского национального университета имени Олеся Гончара.

Твердоступ Микола Іванович - доцент, к.т.н., доцент кафедри електронних обчислювальних машин Дніпровського національного університету імені Олеся Гончара.

Tverdostup Mukola Ivanovich - Associate Professor of Computer Systems Engineering Department of the Oles Honchar Dnipro National University. 